\title{
Pengelolaan Ekowisata Boonpring oleh Badan Usaha Milik Desa (BUMDes) dalam Meningkatkan Pendapatan Asli Desa
}

Jurnal Akuntansi Terapan Indonesia

Affiliation:

Universitas Muhammadiyah Malang, Indonesia

\section{*Correspondence:}

driana@umm.ac.id

This Article is Avalilable in:

https://journal.umy.ac.id/index.php/jat i/article/view/12414

DOI:

https://doi.org/10.18196/jati.v4i2.124 14

\section{Citation:}

Leniwati, D., \& Aisyah, A. (2021).

Pengelolaan Ekowisata Boonpring oleh Badan Usaha Milik Desa (BUMDes) Dalam Meningkatkan Pendapatan Asli Desa. Jati: Jurnal Akuntansi Terapan Indonesia, 4(2), 127-139.

Article History
Received:
12 Agustus 2021
Reviewed:
04 October 2021
Revised:
27 October 2021
Accepted:
29 October 2021
Topic Article:
Sector public accounting,

Accounting for SME's
Driana Leniwati*, Aliya Nur Aisyah

\begin{abstract}
:
The aimed of this study was to analyze the management of Boonpring Ecotourism by Village Owned Enterprises (BUMDes) in order to increase income of the village (PADes). This study uses a case study design with a qualitative descriptive method. Qualitative data obtained by conducting in depth interviews, observations and documentation. The informants in this study were the Head of village, the Head of BUMDes, staff and community. Data reduction, data presentation, trianggulation and conclusion are data analysis used in this study. The results of the study stated that the management of Boonpring Ecotourism had been carried out well by the Village-Owned Enterprises (BUMDes) of Sanan Kerto in accordance with the cooperative, participatory, transparent, accountable, and sustainable principles. Good management of Boonpring Ecotourism is expected to increase Income of village in a sustainable manner by exploring the potential of villages through the tourism sector even though there are obstacles in the application of participatory principles, namely the quality of Human Resources (HR) that need to be trained.
\end{abstract}

Keywords: Management Principles, Tourism, BUMDes, Income of Village.

\begin{abstract}
Abstrak:
Tujuan dari penelitian ini adalah untuk menganalisis pengelolaan Ekowisata Boonpring oleh Badan Usaha Milik Desa (BUMDes) dalam rangka meningkatkan pendapatan desa (PADes). Penelitian ini menggunakan desain studi kasus dengan metode deskriptif kualitatif Data kualitatif diperoleh dengan melakukan wawancara secara mendalam, observasi dan dokumentasi. Informan dalam penelitian ini adalah Kepala Desa, kepala BUMDes, karyawan, dan masyarakat. Reduksi data, penyajian data, trianggulasi dan penarikan kesimpulan merupakan analisis data yang digunakan dalam penelitian ini. Hasi penelitian menyatakan pengelolaan Ekowisata Boonpring sudah dilakukan dengan baik oleh Badan Usaha Milik Desa (BUMDes) Sanan kerto sesuai dengan prinsip kooperatif, partisipatif, emansipatif, transparan, akuntable, dan sustainable. Pengelolaan Ekowisata Boonpring yang baik diharapkan dapat meningkatkan Pendapatan Asli Desa secara berkelanjutan dengan menggali potensi desa melalui sektor pariwisata walaupun ada kendala dalam penerapan prinsip partisipatif yaitu kualitas Sumber Daya Manusia (SDM) yang perlu dilatih.
\end{abstract}

Kata Kunci: Prinsip Pengelolaan, wisata, BUMDes, PADes.

\section{PENDAHULUAN}

Undang-undang No. 32 Tahun 2004 menyebutkan bahwa pemerintah desa dianjurkan untuk mendirikan Badan Usaha Milik Desa (BUMDes) yang berguna untuk mengatur perekonomian desa dan memenuhi kebutuhan serta menggali 
potensi desa, dan Undang-undang ini merupakan salah satu upaya dari pemerintah pusat dalam meningkatkan peran desa untuk ikut berkecimpung dan turun tangan langsung dalam meningkatkan perekonomian desa. Hal ini diperkuat dengan Undangundang Nomor 6 Tahun 2014 tentang Desa dalam mengembangkan potensi yang dimilikinya secara mandiri sesuai kebutuhan dalam rangka mewujudkan kesejahteraan masyarakat. Hal ini diperkuat oleh Peraturan Menteri Desa, Daerah Tertinggal dan Transmigrasi Nomor 4 tahun 2015 tentang Pendirian, Pengurusan dan Pengelolaan, dan Pembubaran Badan Usaha Milik Desa yang di dalamnya menyebutkan bahwa desa dapat mendirikan Badan Usaha Milik Desa (BUMDes).

Di Indonesia terdapat 2.188 Badan Usaha Milik Desa (BUMDes) yang mangkrak atau tidak beroperasi, akan tetapi terdapat 1.670 Badan Usaha Milik Desa (BUMDes) yang berjalan tapi belum optimal berkontribusi menggerakkan ekonomi desa. Oleh karena itu BUMDes "harus direvitalisasi". Salah satu caranya adalah dengan masuk ke sektor produktif seperti bisnis pasca-panen yang memiliki nilai ekonomi atau pariwisata Tirto.id, (2019). Pengembangan sektor pariwisata bisa dilihat dalam skala pemerintahan desa. Banyak potensi pariwisata alam yang berada pada wilayah perdesaan. Desa dengan potensi pariwisata yang dikelola dengan baik dapat meningkatkan perekonomian masyarakat. Karena itu, otonomi desa sesuai Undang-Undang Nomor 6 Tahun 2014 tentang Desa memberikan peluang yang luas kepada desa untuk mengelola potensi desa yang ada. Pemerintah desa dapat membentuk BUMDes dengan unit usaha yang mengelola sumber daya dengan potensi desa yang ada Teras Desa co.id , (2020).

Penelitian sebelumnya mengatakan bahwa pengelolaan obyek wisata oleh Badan Usaha Milik Desa (BUMDes) dapat meningkatkan ekonomi masyarakat Desa. Hal ini dibuktikan dengan adanya fenomena terjadinya peningkatan penghasilan pada masyarakat Desa setelah mengikuti program BUMDes salah satunya adalah objek wisata (Saragi \& Abdullah, 2020). Sedangkan penelitian Trivena Y.P. Karinda, (2020) menunjukkan bahwa tata kelola BUMDes dikaji dengan melihat panduan pendirian pengelolaan BUMDes yang mewajibkan prinsip Kooperatif, Partisipatif, Transparansi, dan Akuntabel. Walaupun masih banyak yang harus dibenahi terkait dengan pengelolaan BUMDes sebagaimana penelitian Filya, (2018) menunjukkan bahwa pengelolaan BUMDes sudah berjalan baik namun masih belum optimal, dikarenakan belum terpenuhi beberapa indikator yaitu tenaga kerja, modal, pangsa pasar, akuntabel dan peningkatan laba/rugi. Apapun ini, keberadaan BUMDes dapat meningkatkan kemandirian dan kesejahteraan masyarakat desa sehingga mampu menggerakkan ekonomi perdesaan. Bahkan disebutkan desa wisata Bulusur sebagai obyek penelitian penelitian ini telah memberikan kontribusi pendapatan asli desa (PADes) secara signifikan meningkat dan menyediakan lapangan kerja bagi masyarakat usia produktif (Putri Nugrahaningsih, (2018); Endah, (2018); Ma'ruf et al., (2017).

Dari penelitian sebelumnya dapat diketahui bahwa keberadaan BUMDes sangat penting di dalam mengelola potensi desa dalam hal ini sektor wisata. Dengan pengelolaan sektor wisata yang baik maka akan berdampak pada Pendapatan Desa. Sehingga penelitian ini penting untuk dilakukan untuk mengetahui dan menganalisis pengelolan Ekowisata Boonpring oleh BUMDes. BUMDes Sanan Kerto dipilih sebagai obyek penelitian pada penelitian ini karena BUMDes ini dianggap berhasil didalam memaksimalkan potensi desa yaitu Ekowisata Boonpring. Ekowisata Boonpring yang sudah ada sejak tahun 1978 yang awalnya hanya digunakan masyarakat untuk mencari rumput untuk makanan ternaknya dan mencari kayu bakar, maka dengan keberadaan BUMDes pada tahun 2017 Ekowisata Boonpring dikelola dan memberikan kontribusi terbesar pada peningkatan jumlah PADes Desa Sanankerto. Adapun perkembangan pendapatan yang diperoleh BUMDes Kerto Raharjo mengalami kenaikan setiap tahunnya. Peningkatan jumlah PADes Desa Sanankerto tentunya tidak lepas dari pengelolaan BUMDes yang baik. Hal inilah yang memotivasi peneliti untuk meneliti lebih lanjut Bagaimana BUMDes mengelola Ekowisata Boon Pring 
sehingga dapat memberikan Pendapatan Desa yang berkelanjutan sampai dengan sekarang.

Pendapatan Desa yang berkelanjutan adalah tujuan utama dari berdirinya BUMDes. Prinsip pengelolaan yang baik sebagaimana terdapat dalam Peraturan Desa Nomor 5 Tahun 2016 tentang Pendirian, Pengurusan Dan Pengelolaan Badan Usaha Milik Desa dalam Bab III Pasal 4 yang menyatakan BUMDesa dikelola berdasarkan prinsip transparansi, akuntabel, partisipatif, sustainable, emansipatif serta dilakukan dengan tertib dan disiplin anggaran dengan semangat kekeluargaan, kegotongroyongan dan kerjasama yang baik. Penerapan prinsip-prinsip di atas pada masyarakat Sanan Kerto tentunya berbeda ketika diterapkan pada masyarakat daerah lain sebagaimana yang sudah dilakukan pada penelitian sebelumnya. Perbedaan itu akan tampak dari budaya gotong royong, kekeluargaan, dan kerjasama dari masyarakat Sanan kerto yang tertuang pada Peraturan Desa Nomor 5. Bagaimana budaya ketika diterapkan ke dalam prinsip-prinsip transparansi, akuntabel, partisipatif, sustainable, emansipatif ditanbah dengan nilai-nilai keagamaan yang kuat dari desa Sanan Kerto ini tentunya membedakan dengan penelitian sebelumnya dan menarik untuk diteliti lebih lanjut.

Berdasarkan fenomena yang ada, penelitian sebelumnya serta refrensi di atas maka peneliti tertarik untuk melakukan penelitian lebih lanjut terkait "Bagaimana pengelolaan Ekowisata Boonpring oleh BUMDes Sanan Kerto dalam meningkatkan Pendapatan Desa". Penelitian ini diharapkan dapat memberikan kontribusi referensi kepada akademisi dan praktisi BUMDes terkait pengelolaan sektor wisata oleh BUMDes.

\section{METODE PENELITIAN}

BUMDes adalah bentuk badan usaha yang seluruh atau sebagian modalnya dimiliki oleh desa melalui penyertaan modal langsung yang berasal dari hasil kekayaan dan potensi desa. Lembaga ini diprediksi menjadi kekuatan besar yang akan mendorong terciptanya peningkatan kesejahteraan dengan berbagai cara, salah satunya dengan menciptakan produktivitas ekonomi bagi desa berdasar pada keberagaman potensi yang dimiliki desa (Undang-Undang No. 6 Tahun 2014, 2014). BUMDes juga dapat diartikan sebagai usaha yang dicirikan desa yang didirikan secara Bersama-sama oleh pemerintah desa bersama dengan masyarakat desa. Dimana badan usaha ini memiliki tugas untuk dapat menggunakan potensi ekonomi serta potensi sumber daya alam dan potensi sumber daya manusia dalam meningkatkan tingkat kesejahteraan masyarakat desa. Keberadaan BUMDes menjadi salah satu badan usaha yang didorong untuk menghasilkan Pendapatan Asli Desa. Hal ini sesuai dengan pengertian BUMDes yang diatur dalam Undang-Undang No. 32 tahun 2004 tentang pemerintah desa yang mengamanatkan bahwa BUMDes didirikan salah satunya untuk meningkatkan Pendapatan Asli Desa (PADes).

Penetian ini menggunakan pendekatan deskriptif kualitatif. Penelitian Deskriptif menggambarkan obyek penelitian terkait dengan tema yang di angkat (Ihyaul Ulum \& Ahmad Juanda, 2018). Jadi penelitian ini bertujuan untuk menjawab fenomena dalam memahami kontak sosial secara alami terlebih dahulu selanjutnya mengedepankan proses interaksi komunikasi yang mendalam antara peneliti dengan fenomena yang diteliti.

Penelitian dilaksanakan di Desa Sanankerto Kecamatan Turen Kabupaten Malang. Dalam penelitian ini yang menjadi unit analisis adalah pengelola BUMDes Kerto Raharjo seperti kepala desa, direktur utama BUMDes, Sekertaris BUMDes, Bendahara BUMDes karyawan dan masyarakat. Sumber data dalam penelitian ini yaitu data primer berupa hasil wawancara langsung dengan informan dan data sekunder berupa data-data yang bersifat keuangan dari obyek penelitian. Teknik analisis data dalam penelitian ini yaitu proses reduksi data, penyajian data, trianggulasi pengambilan kesimpulan atau verifikasi. 
Teknik pengumpulan data yang dalam penelitian ini dilakukan dengan observasi, wawancara dan dokumentasi. Wawancara dilakukan secara mendalam kepada informan dengan wawancara terstruktur dan tidak terstruktur. Informan kunci pada penelitian ini 4 orang yang terdiri dari kepala desa, Direktur Utama BUMDes, Karyawan, dan Masyarakat. Informan ini dipilih karena dianggap bisa memberikan informasi di dalam menjawab rumusan masalah yaitu bagaimana pengelolaan Ekowisata Boon Pring oleh BUMDes sehingga dapat meningkatkan Pendapatan Desa. Kepala Desa dalam hal ini mewakili struktural pemerintah, Direktur BUMDes mewakili BUMDes, dan karyawan dan masyarakat merupakan pelaku yang merasakan apakah pengelolaan Ekowisata oleh BUMDes sudah dilakukan dengan baik sehingga memberikan dampak yang positif kepada karyawan dan masyarakat sekitar Ekowisata Boon Pring. Keberadaan karyawan dan Masyarakat ini juga sebagai data trianggulasi dalam mendapatkan data yang valid dan reliabel. Adapun informan terdapat pada tabel dibawah ini :

Tabel 1. Informan Penelitian

\begin{tabular}{clll}
\hline No & \multicolumn{1}{c}{ Nama Informan } & \multicolumn{1}{c}{ Pendidikan } & \multicolumn{1}{c}{ Jabatan } \\
\hline 1 & H. Mohammad Subur, SE & S1/Manajemen & Kepala Desa Sanankerto \\
2 & Drs. H. Samsul Ariffin, M. Si & $\begin{array}{l}\text { S2/ Magister } \\
\text { Sains }\end{array}$ & $\begin{array}{l}\text { Direktur Utama Badan } \\
\text { Usaha Milik Desa } \\
\text { (BUMDes) Kerto Raharjo }\end{array}$ \\
& & SD & $\begin{array}{l}\text { Karyawan Ekowisata } \\
\text { Boonpring }\end{array}$ \\
3 & Sutrisno & & $\begin{array}{l}\text { Penjual Yang Ada Di } \\
\text { Kawasan Boonpring }\end{array}$ \\
& Rosida & SMP &
\end{tabular}

\section{HASIL DAN PEMBAHASAN}

\section{Kontribusi BUMDes Kerto Raharjo pada Pengelolaan Ekowisata Boonpring Terhadap Peningkatan Pendapatan Asli Desa}

Keberadaan BUMDes diperlukan untuk meningkatkan Pendapatan Asli Desa agar Desa dapat memanfaatkan potensi-potensi yang ada dengan baik sehingga dapat meningkatkan jumlah pendapatan asli desa. Hal ini dapat di lihat pada tabel dibawah sebagai berikut:

Tabel 2. Bagi Hasil Usaha (SHU) BUMDes Kerto Raharjo

\begin{tabular}{clccc}
\hline No & \multicolumn{1}{c}{ Uraian } & Presentase & $\begin{array}{c}\text { Jumlah SHU } \\
\text { Tahun 2019 }\end{array}$ & $\begin{array}{c}\text { Jumlah SHU } \\
\text { Tahun 2020 }\end{array}$ \\
\hline 1 & Untuk Cadangan Umum & $5 \%$ & 72.305 .399 & 86.556 .385 \\
2 & Dana Pengembangan Usaha & $20 \%$ & 289.221 .595 & 346.225 .539 \\
3 & Dana Karyawan & $10 \%$ & 144.610 .797 & 173.112 .769 \\
4 & Dana Kesehatan & $1 \%$ & 14.461 .080 & 17.311 .277 \\
5 & Jasa Purna Bakti & $3 \%$ & 43.383 .239 & 51.933 .831 \\
6 & Pembinaan dan Pelatihan & $5 \%$ & 72.305 .399 & 86.556 .385 \\
7 & Dana Pengurus & $10 \%$ & 144.610 .797 & 173.112 .769 \\
8 & Dana Pengawas & $7 \%$ & 101.227 .558 & 121.178 .939 \\
9 & Untuk PADes & $39 \%$ & 433.832 .393 & 519.338 .309 \\
TOTAL SHU & $100 \%$ & 1.446 .107 .975 & 1.731 .127 .695 \\
\hline
\end{tabular}

Sumber: Arsip BUMDes Kerto Raharjo

Berdasarkan data di atas merupakan dana bagi hasil dari Ekowisata Boonpring yang dikelolaan oleh BUMDes, hal tersebut diperkuat dengan pernyataan yang diungkapkan oleh 
Bapak Samsul Ariffin, selaku Direktur Badan Usaha Milik Desa (BUMDes) Kerto Raharjo sebagai berikut:

"Untuk PADes berdasarkan presentase bagi hasil usaha yang tertera dalam $A D$ (Anggaran Dasar) ya mbak. Jadi mbak kalau pendapatan Boonpring naik otomatis PADes juga akan ikut naik gitu." (Wawancara 3 Mei 2020).

Keberhasilan dalam mengembangkan potensi yang ada di desa sehingga meningkatkan Pendapatan Asli Desa yang tentu saja sangat bermanfaat bagi masyarakat dan juga pembangunan desa. Hal ini sejalan dengan Ayu \& Desi, (2017) peran BUMDes diperlukan untuk meningkatkan Pendapatan Asli Desa agar desa dapat memanfaatkan potensi-potensi yang ada dengan baik sehingga dapat meningkatkanjumlah Pendapatan Asli Desa. Keberhasilan pengelolaan dan peningkatan Pendapatan Asli Desa ini tidak terlepas dari peran pemerintah desa dalam mengelolah potensi-potensi desa yang dimiliki. Peningkatan usaha Pendapatan Asli Desa dapat dilihat dalam pelaksanaan pembagian hasil usaha BUMDes Kerto Raharjo dalam pengelolaan wisata sudah mampu memberikan kontribusi terhada Pendapatan Asli Desa (PADes). Berdasarkan dari tabel diatas bahwa jumlah kontribusi BUMDes Kerto Raharjo terhadap Pendapatan Asli Desa (PADes) pada tahun 2019 sampai 2020 sebanya 39\% dari pendapatan. BUMDes Kerto Raharjo memberikan dampak positif dalam perekonomian Desa Sanankerto. Berdasarkan tabel diatas diketahui pengelolaan Ekowisata Boonpring memberikan pendapatan bagi desa yang begitu besar. Tentunya hal itu tidak lepas dari penerapan prinsip-prinsip kooperatif, partisipatif, transparansi, akuntabel, dan sustanaible.

\section{Penerapan Prinsip-Prinsip Pengelolaan Badan Usaha Milik Desa pada Ekowisata Terhadap Peningkatan Pendapatan Asli Desa}

\section{Prinsip Kooperatif (Kerjasama)}

Penerapan prinsip kerjasama dalam pengelolaan wisata yang dilakukan oleh BUMDes sudah dikatakan baik dalam kegiatan mengelolah sektor wisata, yakni antara BUMDes dan masyarakat sekitar. kerjasama tersebut dilakukan dengan berbagai pihak dengan orientasi saling menguntungkan, diantaranya di lakukan dengan agen BNI'46 dan perguruan tinggi. Hal ini diungkapkan oleh Direktur Utama BUMDes Kerto Raharjo sebagai berikut:

"Untuk saat ini pihak swasta yang kita ajak Kerjasama salah satunya BNI. Jadi pihak BNI memberikan bantuan tambahan modal dari kredit usaha rakyat kepada pedagang di Kawasan wisata Boonpring. Atas Kerjasama ini kita juga mendapat dana tanggungjawab sosial (CSR). Diman Kerjasama ini dalam bentuk simbosis mutualistis atau saling menguntungkan ya, kan BUMDes juga membuka agen46" (Wawancara 3 Mei 2021). berikut :

Selanjutnya hal tersebut juga dinyatakan oleh Kepala Desa Sanankerto sebagai

"BUMDes juga berkolaborasi dengan Universitas Muhammadiyah Malang dan PT Bank Negara Indonesia (BNI) dalam mengembangkan energi baru dengan melakukan pembangunan Pembangkit Listrik Tenaga Mlkro Hidro (PLTMH) di Kawasan Ekowisata Boonpring untuk mendukung konservasi sumber air di Boonpring" (Wawancara 4 Mei 2021). 
Prinsip kooperatif dalam pengelolaan BUMDes pada Ekowisata Boon pring untuk meningkatkan pendapatan asli desa yaitu semua pihak yang terlibat dalam pengelolaan BUMDes sudah memiliki hubungan kerja yang baik agar proyek dapat diselesaikan dengan baik. Dalam prinsip kooperatif kepercayaan sangat diperlukan kepada stakeholder ataupun pihak luar yang bekerjasama dalam pengembangan usaha dengan BUMDes. BUMDes Kerto raharjo sudah mampu melakukan kerjasama yang baik untuk pengembangan dan keberlangsungan hidup usahanya.

Berdasarkan hasil penelitian diatas maka peneliti menyajiakan tabel dimana memperjelas terakait kesesuaian terhadap indikator dalam prinsip pengelolaan BUMDes sebagai berikut:

Tabel 3. Indikator Prinsip Kooperatif Pengelolaan BUMDes

\begin{tabular}{|c|c|c|}
\hline Prinsip & Indikator & Hasil Wawancara \\
\hline \multirow[t]{2}{*}{ Kooperatif } & $\begin{array}{l}\text { Melakukan kerja sama pihak BUMDes } \\
\text { dan pihak lain dalam pengembangan } \\
\text { usaha }\end{array}$ & $\begin{array}{l}\text { Pihak swasta yang BUMDes Kerto } \\
\text { Raharjo ajak Kerjasama salah satunya } \\
\text { BNI. Dimana pihak BNI memberikan } \\
\text { bantuan tambahan modal dari kredit } \\
\text { usaha rakyat kepada pedagang di } \\
\text { Kawasan wisata Boonpring. BUMDes } \\
\text { juga berkolaborasi dengan Universitas } \\
\text { Muhammadiyah Malang dan PT Bank } \\
\text { Negara Indonesia (BNI) dalam } \\
\text { mengembangkan energi baru dengan } \\
\text { melakukan pembangunan Pembangkit } \\
\text { Listrik Tenaga Mkro Hidro (PLTMH) } \\
\text { di Kawasan Ekowisata Boonpring }\end{array}$ \\
\hline & $\begin{array}{l}\text { Melibatkan terjalinnya komunikasi } \\
\text { antara pemerintah desa dan masyarakat } \\
\text { sehingga berpengaruh pada peningkatan } \\
\text { pendapatan. }\end{array}$ & $\begin{array}{l}\text { Didalam pengelolaan } \text { BUMDes } \\
\text { terdapat komponen yang terlibat } \\
\text { dimana sudah mampu melakukan } \\
\text { kerjasama dengan baik. selama ini } \\
\text { Pemerintah Desa, BPD dan masyarakat } \\
\text { yang terlibat sudah menjalin } \\
\text { komunikasi dengan baik sehingga } \\
\text { BUMDes Kerto Raharjo bangkit dan } \\
\text { sekarang mampu meningkatkan } \\
\text { perekonomian desa melalui wisata desa }\end{array}$ \\
\hline
\end{tabular}

\section{Prinsip Partisipatif}

Prinsip partisipatif pada Ekowisata Boon pring sudah dapat meningkatkan pendapatan asli desa. Semua pihak yang terlibat dalam BUMDes maupun Pemerintah desa dan masyarakat bersedia memberikan dukungan dan kontribusi yang dapat mendorong kemajuan unit usaha BUMDes. Partisipasi masyarakat maupun pemerintah desa merupakan pilar utama dalam pengembangan unit usaha BUMDes salah satunya dalam mengembangkan unit usaha Ekowisata Boon pring. Berdasarkan hasil penelitian menunjukkan bahwa pemerintah melakukan partisipatif dengan memberikan penyertaan modal sedangkan masyarakat melakukan kegiatan partisipatif dengan merawat, melestarikan serta mendukung dalam berbagai program kegiatan pengelolaan Ekowisata Boon pring yang telah direncanakan oleh BUMdes dalam meningkatkan daya tarik pada sektor wisata. Hal ini diperkuat dengan pernyataan Direktur BUMDes Kerto Raharjo Sebagai berikut:

"BUMDes Kerto Raharjo memberi wewenang kepada kelompok sadar wisata maupun karang taruna untuk ikut serta mengelola wisata Boonpring, yaitu dengan pemberian 
tugas sebagai driver, penjaga parkir, dan penjaga loket serta memperhatikan kebersihan lingkungan sekitar. Pembagian tugas yang diberikan kepada kelompok sadar wisata tersebut dijalankan oleh pemuda pemudi karang taruna yang secara bergantian dalam menjaga loket wisata, menjadi driver untuk mengantar pengunjung keliling wisata Boonpring menggunakan perahu boot".

Pengelolaan Ekowisata yang melibatkan masyarakat dengan tujuan untuk meningkatkan kondisi ekonomi masyarakat dengan menciptakan peluang usaha dan lapangan kerja bagi masyarakat setempat. Dimana masyarakat adalah bagian terpenting dari sebuah desa, saat masyarakat bergotong-royong ikut serta dalam peningkatan pengelolaan potensi yang dimiliki desa. Hal tersebut juga dirasakan oleh masyarakat adanya ikutserta masyarakat dalam pengelolaan Ekowisata Boonpring memberikan lapangan pekerjaan baru, Seperti yang dirasakan oleh karyawan Ekowisata Boonpring sebagai berikut:

"Disini kan banyak anak muda lulusan sekolah menengah yang pengangguran mbak jadi alhamdulillah mbak dengan adanya pengelolaan wisata Boonpring ini dapat memberikan lapangan pekerjaan bagi saya dan yang lainnya. Saya sendiri yang dulunya buruh tani sekarang dapat bekerja disini jadi ya dapat meningkatkan perekonomian keluarga".

Adanya dukungan dari pemerintah desa yang ditunjukkan dengan pemberian modal yang menjadi modal awal dalam berdirinya BUMDes Kerto Raharjo. Seperti keterangan yang diberikan oleh Bapak Syamsul Arifin selaku Direktur Utama BUMDes Kerto Raharjo sebagai berikut:

"Sumber keuangan BUMDes diberikan oleh pemerintah desa pada awalnya pembentukan BUMDes yang didapatkan dari Alokasi Dana Desa (ADD) sebesar 470 juta rupiah kemudian yang 170 juta untuk pengembangan wisata karena Boonpring kan termasuk unit usaha pertama kita yaa mbak." (Wawancara 3 Mei 2021).

Prinsip partisipatif dalam meningkatkan pendapatan Pendapatan Asli Desa sudah terlaksana. Hal ini dapat dilihat dari komponen yang terlibat seperti pemerintah desa, BPD dan masyarakat dalam BUMDes Kerto Raharjo sudah menunjukkan dukungan dan kontribusi kepada pengelolaan unit usaha Ekowisata Boon pring yang dilakukan oleh BUMDes Kerto Raharjo dengan ikut membantu mengelola dan mengembangkan potensi desa. Kontribusi dari pemerintah desa sudah dijalankan dengan memberikan penyertaan modal kepada BUMDes Kerto Raharjo. Dukungan dari masyarakat desa juga sudah diberikan, hal ini dapat dilihat dari masyarakat yang peduli dengan pontesi yang ada di desa, masyarakat desa terlibat dalam bentuk sosialisasi baik secara langsung maupun tidak langsung seperti ikut dalam melestarikan dan mengembangkan Ekowisata Boon pring serta mengikuti setiap program yang dilaksanakan oleh BUMDes dan menjadi bagian dari pengurus BUMDes.

Berdasarkan hasil penelitian diatas maka peneliti menyajiakan tabel dimana memperjelas terakait kesesuaian terhadap indikator dalam prinsip pengelolaan BUMDes sebagai berikut: 
Tabel 4. Indikator Prinsip Partisipatif Pengelolaan BUMDes

\begin{tabular}{|c|c|c|}
\hline Prinsip & Indikator & Hasil Wawancara \\
\hline \multirow[t]{2}{*}{ Partisipatif } & $\begin{array}{l}\text { Mekanisme Partisipasi } \\
\text { masyarakat dalam } \\
\text { pengembangan usaha }\end{array}$ & $\begin{array}{l}\text { Adanya partisipasi masyarakat } \\
\text { akan mampu mengimbangi } \\
\text { keterbatasan biaya dan } \\
\text { kemampuan Pemerintah Desa } \\
\text { dalam mengelola BUMDes. }\end{array}$ \\
\hline & $\begin{array}{l}\text { Pendirian BUMDes yang } \\
\text { disepakati perangkat desa } \\
\text { dengan pemberian modal. }\end{array}$ & 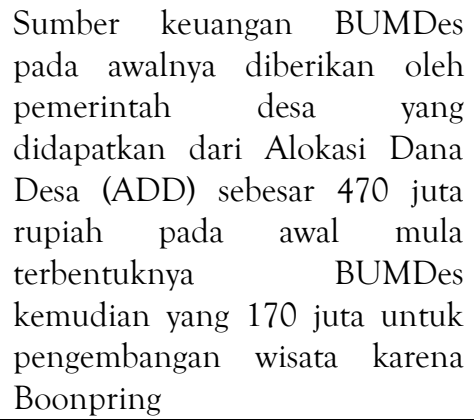 \\
\hline
\end{tabular}

\section{Prinsip Transparansi (Keterbukaan)}

Prinsip transparansi untuk mengetahui dan mendapatkan akses informasi seluasluasnya tentang keuangan daerah kepada masyarakat. BUMDes merupakan lembaga ekonomi yang beroperasi di desa yang berdasarkan kejujuran dan keterbukaan oleh sebab itu pengelolaan BUMDes harus transparan. Pentingnya Transparansi dalam pengelolaan yang baik untuk melihat keberhasilan BUMDes yang dijalankan supaya bisa terlaksana sesuai dengan tujuan awal yang ingin dicapai.

BUMDes Kerto Raharjo setiap 6 bulan sekali melaporkan laporan keuangan dan laporan program kerja yang disusun dalam laporan pertanggungjawaban (LPJ). Dalam laporan pertanggungjawaban BUMDes Kerto Raharjo berisis tentang seluruh evaluasi dari kegiatan yang telah dilakukan mulai dari pengeluaran dana serta pengelola yang bertanggungjawab pada setiap kegiatan yang dilakukan oleh BUMDes. Laporan pertanggungjawaban dilakukan untuk memudahkan pemangku kepentingan dalam pengambilan keputusan, baik jangka pendek atau jangka panjang. Selain itu, laporan pertanggungjawaban yang dilakukan 2 (dua) kali per tahun dimaksudkan untuk mengetahui kondisi BUMDES di tahun ini. Kegiatan tersebut melibatkan unsur masyarakat seperti RT/RT BPD, serta pemerintah Desa Sanankerto. Hal tersebut juga diperkuat dengan penjelasan Direktur Utama BUMDes Kerto Raharjo yaitu:

"Laporan pertanggungjawaban melibatkan warga, RT/RW, BPD, dan seluruh perangkat desa yang dilakukan setiap 6 bulan sekali mbak... bahkan mbak kalua ada dari pihak luar pun yang ingin mengetahui LPJ itu bisa diakses dalam bentuk buku di kantor sekertariatan BUMDes ya.." (Wawancara 3 Mei 2021).

Prinsip tranparansi pada BUMDes Kerto Raharjo sudah dilaksanakan dengan baik dalam menyediakan informasi BUMDes Kerto Raharjo salah satunya memberikan informasi terkait laporan pertanggungjawaban dan dalam pengambilan keputusan dalam kegiatan BUMDes selalu melibatkan masyarakat dan pemerintah desa, jadi dapat dikatakan keterbukaan dalam proses pengelolaan BUMDes Kerto Raharjo sudah terlaksanakan. Pakaya \& Rorong, (2019) masyarakat harus terlibat secara langsung dari perencanaan, pelaksanaan hingga pengambilan keputusan. prinsip transparansi berkaitan dengan meningkatnya pendapatan asli Desa karena prinsip ini mengedepankan keterbukaan data pada setiap pengelola BUMDes, pemerintah Desa dan masyarakat. 
Berdasarkan hasil penelitian diatas maka peneliti menyajiakan tabel dimana memperjelas terakait kesesuaian terhadap indikator dalam prinsip pengelolaan BUMDes sebagai berikut:

Tabel 5. Indikator Prinsip Transparansi Pengelolaan BUMDes

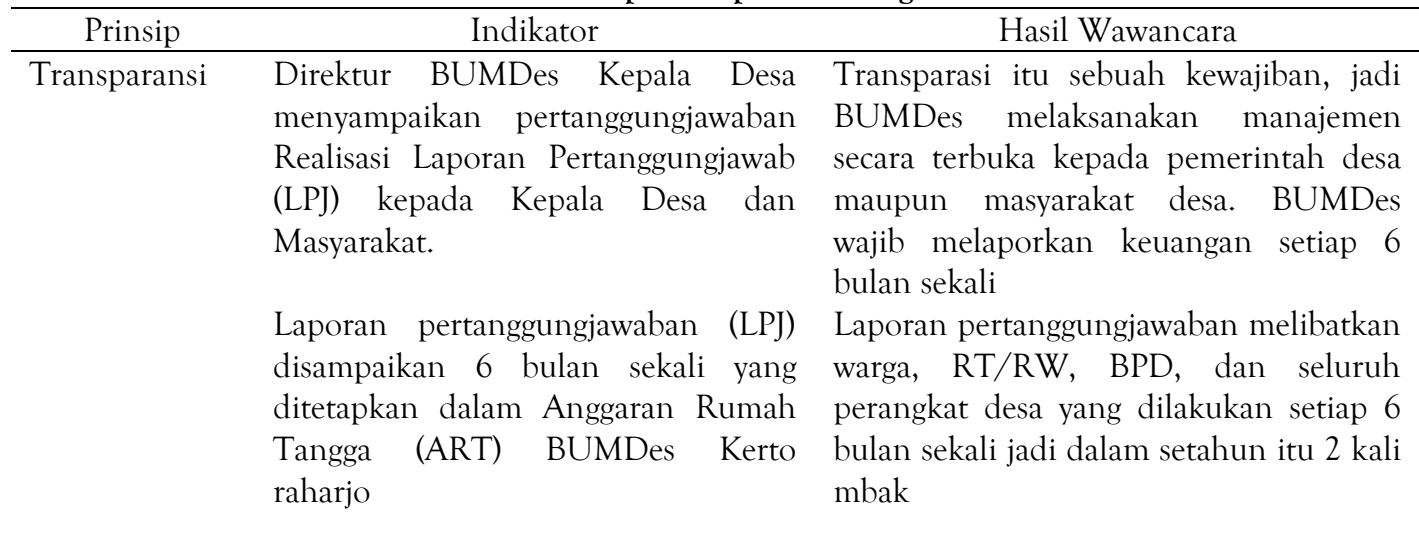

\section{Prinsip Akuntabel (Pertanggungjawaban)}

Prinsip akuntabel berkaitannya dengan pertanggungjawaban kepada masyarakat maupun pemerintah desa, transparasi dan pengungkapan laporan keuangan. Dalam akuntabel dasar pelaporan keuangan dimana masyarakat berhak untuk mengetahui catatan laporan keuangan yang ada pada pengelolaan ekowisata boonpring yang dilakukan oleh BUMDes. Prinsip akuntabel ini sudah diterapkan dan dijalankan dalam pengelolaan ekowisata yang dilakukan oleh BUMDes Kerto Raharjo. Dapat diketahui dalam unit usaha ekowisata bahwa BUMDes Kerto Raharjo membuat catatan pelaporan keuangan mengenai pengembangaan ekowisata sesuai dengan peraturan AD/ART laporan keuangan dilaporkan pada setiap setahun dua sekali. Selain itu adanya pertanggungjawaban yang dilakukan oleh kepala unit kepada Direktur BUMDes melalui koordinasi internal. Hal ini tentunya akan memudahkan pengetahuan bagaimana perkembangan sektor wisata yang dilakukan oleh dengan melihat hasil dari tugas-tugas dan tanggungjawab yang sudah dilaksanakan. Tanggungjawab dilakukan meyesuaikan dengan peraturan yang terdapat pada AD/ART sehingga dalam mengerjakan tugas dan tanggungjawab selalu berpedoman pada AD/ART BUMDes Kerto Raharjo.

Hasil penelitian menunjukkan bahwa pengelolaan BUMDes melalui sektor wisata sudah dapat dipertanggung jawabkan secara keuangan. Hal ini diperkuat dengan pernyataan Direktur Badan Usaha Milik Desa (BUMDes) Kerto Raharjo sebagai berikut:

"untuk laporan keuangan sudah menggunakan sistem pembukuan keuangan standart (Akuntansi) seperti Neraca, Rugi / laba, buku bantu, baku kas daftar inventaris dan lain lainnya sehingga mudah mengetahui perkembangan kondisi keuangan maupun kesehatan BUMDes" (Wawancara 3 Mei 2021).

Dalam pengelolaan ekowisata yang dijalankan oleh BUMDes, berikut laporan keuangan BUMDes yang disajikan dalam table dibawah sebagai berikut:

Tabel 6. Laba Usaha Ekowisata Boonpring tahun 2019-2020

\begin{tabular}{ccc}
\hline & 2019 & 2020 \\
\hline Pendapatan & 2.778 .720 .500 & 3.256 .606 .100 \\
Beban & 1.312 .612 .525 & 1.525 .478 .405 \\
Laba Usaha & $\mathbf{1 . 4 4 6 . 1 0 7 . 9 7 5}$ & $\mathbf{1 . 7 3 1 . 1 2 7 . 6 9 5}$ \\
\hline
\end{tabular}

Sumber: Arsip BUMDes Kerto Raharjo

Jati : Jurnal Akuntansi Terapan Indonesia, 2021 | 135 
Berdasarkan dari kondisi keuangan BUMDes tahun 2019 sampai 2021 pada 2019 jumlah dari total pendapatan yang diterima sebesar Rp. 2.77.720.500 dan biaya yang harus dikeluarkan sebesar Rp. 1.312.612.525 sehingga keuntungan yang diterima sebesar Rp. 1.446.107.975. Sedangkan pada tahun 2020 dari total pendapatan yang diterima sebesar Rp. 3.56.606.100 dan biaya yang dikeluarkan sebesar $\mathrm{Rp}$ 1.525.478.405 sehingga keuntungan yang diterima sebesar Rp. 1.731.127.695. Dalam data laporan laba rugi di atas dapat dilihat bahwa pendapatan mengalami peningkatan setiap tahunnya. Direktur Badan Usaha Milik Desa (BUMDes) Kerto Raharjo mengungkapkan pernyataan sebagai berikut:

"Sumber keuangan BUMDes Kerto Raharjo didapatkan dari Alokasi Dana Desa sebesar 470 juta rupiah pada awal terbentuknya BUMDes. Kemudian setelah berjalan pada tahun 2019, sumber keuangan BUMDes dalam mengelola Ekowisata Boonpring adalah dari penghasilan loket itu sendiri, pemasukan dari sewa-sewa kios, kamar mandi, persewaan ban dan dari beberapa fasilitas yang ada di ekowisata seperti flaying fox, perahu dan masih banyak lagi. Eh masih ada lagi itu dari parkir mbak, ya lumayan banyak itu. Jadi pengelolaan tidak lagi meminta alokasi dana desa dikarenakan sudah mampu mengelola keuangan secara mandiri dan berkelanjutan" (Wawancara 3 Mei 2021).

Berdasarkan hasil penelitian diatas maka peneliti menyajiakan tabel dimana memperjelas terakait kesesuaian terhadap indikator dalam prinsip pengelolaan BUMDes sebagai berikut:

Tabel 7. Indikator Prinsip Akuntabel Pengelolaan BUMDes

\begin{tabular}{cllr}
\hline Prinsip & \multicolumn{2}{c}{ Indikator } & \multicolumn{2}{c}{ Hasil Wawancara } \\
\hline Akuntabel & Laporan keuangan & laporan keuangan sudah \\
& BUMDes berdasarkan & menggunakan sistem \\
& standar akuntansi & pembukuan keuangan standart \\
& (Akuntansi) seperti Neraca, \\
& Rugi / laba, buku bantu, baku \\
& kas daftar inventaris dan lain \\
& lainnya . \\
\hline
\end{tabular}

\section{Prinsip Sustainable (Keberlanjutan)}

Dalam prinsip suistainabel, peneliti menilai bahwa BUMDes Kerto Kerto pada Ekowisata Boon pring sudah berjalan baik dalam meningkatkan pendapatan asli desa. BUMDes Kerto Raharjo telah melakukan pengelolaan Ekowisata Boonpring dengan cara mengupayakan pengembangan wisata secara jangka panjang. Pengelolaan ini adalah sebagai bentuk pelestarian potensi Desa Sanankerto yang harus dimanfaatkan lebih baik untuk mensejahterakan masyarakat. Prinsip Suistainable sudah dijalankan dengan baik yang dapat dilihat dalam mengelolah daya tarik wisata. Peningkatan kunjungan dari tahun ke tahun tidak lepas dari inovasi yang terus dikembangkan dan juga didukung oleh prasarana dan sarana yang dimiliki objek wisata. Adanya inovasi yang dilakukan memberikan pengaruh positif terhadap daya tarik wisata yang teru meningkat dan dapat bertahan dalam persaingan usaha. Hal ini dapat dilihat berdasarkan table dibawah: 
Tabel 8. Data Kunjungan Wisata Boonpring 2019 - 2020

\begin{tabular}{|c|c|c|c|}
\hline $\mathrm{No}$ & Bulan & 2019 & 2020 \\
\hline 1 & Januari & 22.757 & 24.708 \\
\hline 2 & Februari & 10.652 & 13.698 \\
\hline 3 & Maret & 8.331 & 2.995 \\
\hline 4 & April & 9.274 & 3.348 \\
\hline 5 & Mei & 5.527 & 5.997 \\
\hline 6 & Juni & 13.149 & 10.378 \\
\hline 7 & Juli & 16.654 & 15.919 \\
\hline 8 & Agustus & 13.336 & 19.407 \\
\hline 9 & September & 9.011 & 15.080 \\
\hline 10 & Oktober & 9.363 & 16.935 \\
\hline 11 & November & 11.788 & 13.381 \\
\hline 12 & Desember & 20.367 & 20.108 \\
\hline & Total & 150.209 & 161.954 \\
\hline
\end{tabular}

Sumber: Arsip BUMDes Kerto Raharjo

Berdasarkan tabel di atas dapat dilihat jumlah wisatawan yang berkunjung pada tahun 2019 sebanyak 150.209 dan tahun 2020 mengalami kenaikan menjadi 161.954. Data tersebut memenuhi syarat untuk menunjang pengelolaan BUMDesa yang berkelanjutan. Jika dilihat dari kunjungan wisata yang mengalami kenaikan dari tahun ke tahun tentunya juga dengan adanya fasilitas yang disediakan oleh pengelola yang terus dikembangkan, sehingga wisatawan merasa nyaman dan ingin datang kembali untuk berwisata di Ekowisata Boonpring. Hal tersebut didukung oleh pernyataan yang diungkapkan Direktur Badan Usaha Milik Desa (BUMDes) Kerto Raharjo sebagai berikut:

"Jadi mbak inovasi harus terus dilakukan, karena wisatawan tidak akan berdatangan jika kita tidak melakukan inovasi. Kami juga melakukan strategi pemasaran yang bertujuan untuk meningkatkan minat kunjungan wisatawan dengan promosi melalui media sosial seperti website, facebook ataupun youtube." (Wawancara 3 Mei 2021).

Keberadaan BUMDes diperlukan untuk meningkatkan Pendapatan Asli Desa agar Desa dapat memanfaatkan potensi-potensi yang ada dengan baik sehingga dapat meningkatkan jumlah pendapatan asli desa. Filya, (2018) dalam sustainabel harus dapat bertahan dalam persaingan usaha, BUMDes harus terus berinovasi dan mempertahankan kualitas usahanya yang dibantu oleh seluruh komponen BUMDes.

Berdasarkan hasil penelitian diatas maka peneliti menyajiakan tabel dimana memperjelas terakait kesesuaian terhadap indikator dalam prinsip pengelolaan BUMDes sebagai berikut :

Tabel 9. Indikator Prinsip Sustainable Pengelolaan BUMDes

\begin{tabular}{cll}
\hline Prinsip & \multicolumn{1}{c}{ Indikator } & \multicolumn{2}{c}{ Hasil Wawancara } \\
\hline Sustainable & Melakukan rencana pengembangan & Jadi mbak inovasi harus terus \\
& usaha yang berkelanjutan & dilakukan, karena wisatawan tidak \\
& akan berdatangan jika kita tidak \\
& melakukan inovasi. Kami juga \\
& melakukan strategi pemasaran yang \\
& bertujuan untuk meningkatkan minat \\
& kunjungan wisatawan dengan promosi \\
& melalui media sosial seperti website, \\
& facebook ataupun youtube \\
\hline
\end{tabular}




\section{Faktor Hambatan Prinsip Pengelolaan BUMDes pada Ekowisata}

Dalam penerapan prinsip pengelolaan BUMDes pada Ekowisata terdapat beberapa hambatan sebagai berikut:

1. Kualitas pemahaman terhadap prinsip-prinsip pengelolaan BUMDes

Pemaham masyarakat tekait prinsip pengelolaan BUMDes masih rendah, hal tersebut juga diperkuat dengan hasil wawancara dengan Direktur BUMDes Kerto raharjo sebagai berikut:

"Jadi mbak prinsip tata kelolah BUMDes dari pengetahuannya masih rendah, jadi kita terus memberikan sosialisasi ataupun pelatihan untuk meningkatkan kemampuan pengetahuan tentang pengelolaan bUMDes yang baik kepada anggota maupun masyarakat, biar sama-sama tau sam-sama mengembangkan wisata gituu kan" (Wawancara 3 Mei 2021).

2. Sumber Daya Manusia

Sumber daya Manusia yang baik dapat dipengaruhi oleh factor Pendidikan, dimana di dalam pengelolaan BUMDes pada Ekowisata ini yang memiliki Pendidikan tinggi hanya sedikit. Hal ini juga diperkuat dengan pernyatakan dari Kepala Desa Sanankerto sebagai berikut:

"Jadi kami sering mengikutkan pengurus BUMDes untuk mengikuti pelatihan kesana kesini. Yaa kemudian dari karyawan juga dari pariwisata mengikuti pelatihan-pelatihan tour gate kemudian mengikuti studi banding kemanamana. Kita juga sering kedatangan studi banding dari luar, jadi dari sini kita dapat bertukar informasi dengan pihak lain atau desa yang lain bagaimana pengelolaan wisatanya dan sebagainya. Itu kan sebuah cara untuk menjadikan sumber daya manusia yang dikita miliki jadi berkualitas ya mbakk..." (Wawancara 4 Mei 2021).

\section{KESIMPULAN}

Berdasarkan hasil penelitian dapat disimpulkan bahwa pengelolan Ekowisata Boonpring oleh BUMDes Kerto Raharjo dalam meningkatkan Pendapatan Asli Desa sudah dilakukan dengan baik. Secara empiris, BUMDes Kerto Raharjo sudah melakukan prinsipprinsip pengelolaan BUMdes. Yang petama BUMDes sudah menerapkan prinsip kooperatif pada Ekowisata Boonpring dengan melakukan kerjasama yang baik antara pengelola BUMDes dengan pemerintah desa, masyarakat maupun pihak ketiga seperti Agen BNI46 dan perguruan tinggi. Yang kedua, BUMdes sudah menerapkam prinsip akuntable pada Ekowisata Boonpring dengan bertanggung jawab terhadap keuangan Ekowisata Boonpring yang dibuktikan dengan laporan keuangan dan administrasi yang rutin dilaporkan setiap dua kali dalam setahun meliputi pertanggungjawaban pada laporan keuangan yaitu Laporan Laba Rugi, Neraca, Arus Kas dan lain-lain. Yang ketiga, BUMdes sudah menerapkam prinsip sustanable pada Ekowisata Boonpring dengan adanya pemasaran dari mulut ke mulut antar masyarakat desa dengan pengunjung sehingga kunjungan wisatawan terus meningkat setiap tahunnya. Keterlibatan masyarakat desa sebagai karyawan di ekowisata Boonpring juga menambah sense of belonging ekowisata Boompring pada masyarakat sehingga masyarakat secara bergotong royong dan kekeluargaan berusaha mengembangkan potensi desa yang mereka miliki sehingga pada akhirnya akan meningkatkan pendapatan Ekowisata Boonpring. Otomatis Pendapatan Asli Desa juga meningkat. Yang keempat, BUMdes sudah menerapkan prinsip partispatif pada Ekowisata Boonpring dengan baik. hal ini dilihat dari adanya dukungan pemerintah dan 
dukungan dari masyarakat sehingga dapat meningkatkan pendapatan asli desa. Akan tetapi terdapat faktor pemhambat dalam prinsip partisipatif yakni berupa sumber daya manusia (SDM) karena rata-rata masyarakat lulusan sekolah menengah pertama yang masih memiliki keterbatasan kemampuan dan pengetahuan. Jadi BUMDes Kerto Raharjo dan pemerintah desa terus memberikan pelatihan dan dengan adanya studi banding agar mereka mampu mengembangkan Ekowisata Boon pring dengan lebih mumpuni dan menjadi SDM yang berkualitas sehingga dapat mengelola wisata dengan baik. Yang kelima, BUMdes sudah menerapkan prinsip transparansi dengan baik dimana BUMDes selalu menyampaikan berbagai informasi terkait dengan pelaksanaan kegiatan keuangan kepada pemerintah desa dan masyarakat secara jelas serta dapat diakses dengan mudah.

Penelitian ini memiliki beberapa keterbatasan yaitu hanya diberikan data oleh pengurus BUMDes selama 2 tahun yaitu pada tahun 2019-2020 sehingga peneliti tidak bisa menganalisis lebih dalam terkait sustainaibility dari Pendapatan Asli Desa dari awal berdiri Ekowisata Boonpring tahun 2017. Oleh karena itu, saran yang dapat peneliti berikan kepada peneliti selanjutnya yaitu agar dapat menambah periode tahun data yang digunakan sehingga dapat lebih melihat pendapatan asli desa secara brkelanjutan.

\section{DAFTAR PUSTAKA}

Ayu, I. G., \& Desi, R. (2017). Optimalisasi Pengelolaan Pendapatan Asli Desa Untuk Meningkatkan Pembangunan Perekonomian Desa Jurusan Akuntansi Program S1 Universitas Pendidikan Ganesha e-Journal S1 Ak Universitas Pendidikan Ganesha. 1(1).

Endah, K. (2018). Mewujudkan Kemandirian Desa Melalui Pengelolaan Badan Usaha Milik Desa. Jurnal Moderat, 4(4), 25-33.

Filya, A. R. (2018). Optimalisasi Pengelolaan Badan Usaha Milik Desa ( Bumdes ) Dalam Meningkatkan Pades di Kecamatan Bojonegoro Kabupaten Bojonegoro Provinsi Jawa Timur. Jurnal Ekonomi Dan Keuangan Publik, 5(1), 19-39. http://ejournal.ipdn.ac.id/JEKP/article/view/393.

Ihyaul Ulum, SE., M.Si., Ak., C., \& Dr. Ahmad Juanda, MM., AK., C. (2018). Metodologi Penelitian Akuntansi.

Ma'ruf, M. F., Kurniawan, B., \& ... (2017). Desa Wisata: Sebuah Upaya Mengembangkan Potensi Desa Dan Meningkatkan Pendapatan Asli Desa (Studi Pada Desa Wisata Bejiharjo Kecamatan Karangmojo .... ... Jurnal Ilmu Administrasi ..., 193-203. http://ejournal.upnjatim.ac.id/index.php/jdg/article/view/1209.

Pakaya, N., \& Rorong, A. (2019). Transparansi Pengolaan Badan Usaha Milik Desa (BUMDes) Di Desa Kamanga Kecamatan Tompaso. Jurnal Administrasi Publik, 5(74).

Putri Nugrahaningsih1, H. M. (2018). Optimalisasi Peran BUMDes Desa Bulusulur Kecamatan Wonogiri Kabupaten Wonogiri Dalam Membangun Desa Wisata. Prosiding PKM-CSR, 1, $1532-1545$.

Saragi, N., \& Abdullah, A. (2020). Peran Badan Usaha Milik Desa Dalam Pengelolaan Objek Wisata di Desa Denai Lama Kecamatan Pantai Labu Kabupaten Deli Serdang. Jurnal Pemberdayaan Masyarakat, 6(2), 17. https://doi.org/10.37064/jpm.v6i2.6894.

Teras desa. (2020). Membangun Pariwisata Daerah Lewat BUMDes. 14 Januari. https://www.google.co.id/amp/s/terasdesa.co.id/membangun-pariwisata-daerah-lewatbumdes/.

Trivena Y.P. Karinda, W. W. A. K. (2020). Tata Kelola Badan Usaha Milik Desa (Bumdes). Jurnal Politico, 9(3).

Vincent Fabian Thomas. (2019). Kenapa Ribuan BUMDes Mangkrak Meski Dana Desa Triliunan Rupiah? 16 Desember. https://tirto.id/kenapa-ribuan-bumdes-mangkrak-meskidana-desa-triliunan-rupiah-enpb. 